\title{
Systemic Sclerosis without Skin Involvement
}

National Cancer Institute

\section{Source}

National Cancer Institute. Systemic Sclerosis without Skin Involvement. NCI Thesaurus. Code C116789.

A condition in which there are visceral manifestations of systemic sclerosis without any cutaneous findings. 